\title{
Impacts of COVID-19 outbreaks on the lower-income groups and attainments of SDGs: a study of the fast-growing commercial capital city, Chittagong, Bangladesh
}

Md. Abdul Fattah and Syed Riad Morshed

Department of Urban and Regional Planning, Khulna University of Engineering and Technology, Khulna, Bangladesh

Md. Mojammel Hoque

Department of Civil Engineering,

Chittagong University of Engineering and Technology, Chittagong, Bangladesh, and

Md. Fazle Rabbi and Irin Akter Dola

Department of Urban and Regional Planning,

Khulna University of Engineering and Technology, Khulna, Bangladesh

\begin{abstract}
Purpose - The emergence of COVID-19 and its spread led to severe social, economic and livelihood impacts around the world. This study documented the socioeconomic impacts of COVID-19 outbreaks and lockdown on the lower-income groups. Also illustrated the impacts on the attainment of SDGs in the context of the slums of Chittagong City.

Design/methodology/approach - Both qualitative and quantitative data have been collected from the 150 respondents through questionnaire surveys in the slums.

Findings - The lockdown led to the decrease of $90 \%$ of the respondents' income level and affected the livelihoods of $97.33 \%$ of the respondents, with an overall score of $3.22 \pm 0.67$ on a four-point Likert-type scale. About $96.67 \%$ of respondents' psychological conditions have been affected high to extreme, with an overall score of $3.19 \pm 0.68$. The pandemic affected $74.67 \%$ of respondents' food habits, $95.33 \%$ of respondents' child education, increased domestic violence and deteriorated social security, basic service facilities and hygiene
\end{abstract}

(C) Md. Abdul Fattah, Syed Riad Morshed, Md. Mojammel Hoque, Md. Fazle Rabbi and Irin Akter Dola. Published in Frontiers in Engineering and Built Environment. Published by Emerald Publishing Limited. This article is published under the Creative Commons Attribution (CC BY 4.0) licence. Anyone may reproduce, distribute, translate and create derivative works of this article (for both commercial and noncommercial purposes), subject to full attribution to the original publication and authors. The full terms of this licence may be seen at http://creativecommons.org/licences/by/4.0/legalcode

The authors are thankful to Asma Amin Rimi, Fahmida Yeasmin Sami, of the Department of Urban and Regional Planning, KUET, and Reshma Afroz Rimi, Department of Urban and Regional Planning, Jahangirnagar University, for their help in data collection. The authors are grateful to the two anonymous reviewers for their comments and suggestions that really helped us to improve the quality and readership of our manuscript.

Funding: This study received no funds.

Conflict of interest/competing interests: The authors declare that they have no known competing financial interests or personal relationships that could have appeared to influence the work reported in this paper.

Availability of data and material: All the materials are included.

Code availability: All the tests performed in SPSS.

Impacts of

COVID-19

outbreaks 
FEBE

2,2

practices among the slum dwellers. The severity of COVID-19 outbreaks on the lower-income people makes it critical for the government to attain the SDG 1, SDG 2, SDG 3, SDG 4, SDG 5 (Target 5.1, 5.2) SDG 6 and SDG 16.

Originality/value - The findings of the study will help governments, policymakers, international organizations to adopt measures to mitigate the effects of the outbreaks.

Keywords Lower-income people, SDGs, COVID-19 outbreaks, Livelihood impact

Paper type Research paper

\section{8}

\section{Introduction}

Since February 2020, the coronavirus disease 2019 (COVID-19) has expanded exponentially in almost all countries. Despite the progress in some countries in handling the epidemic, the daily new cases have been rising about 500 in late February to nearly 600,000 by November, with the possibility of further increases (Rahman et al., 2021). Moreover, the virus is constantly changing the variations, and the infection of each variant is intense. Besides millions of deaths, it has led to acute and severe losses in many economies due to illness and government-mandated social distancing orders. The economies of developing countries have been more vulnerable (Nyadera and Onditi, 2020). Recent studies show that the developing countries are likely to experience infection and mortality rates greater than the developed countries with the limited health capacities of the developing countries. Although research on health effects in developing countries is rapidly increasing, there is little data on the pandemic's effects on the poor. The available evidence-primarily relies on pre-COVID-19 macroeconomic data and simulation models to predict possible future scenarios based on disease spread assumptions. There is a significant possibility that the frequent long-term lockdowns would push many families back into poverty, a condition that Bangladesh has worked hard to overcome in recent decades (Arab News, 2020). In cities, the poor income groups, especially the day laborers, small businessmen, garment workers, are at high risk of losing their income sources. The attainment of Sustainable Development Goals (SDGs) will become a major challenge for developing countries like Bangladesh by mitigating the effects of the pandemic situation.

The global economy has been passing a critical situation since COVID-19 outbreaks. The World Bank estimates that by 2020, 119-124 million people will be living in extreme poverty (less than \$1.90/day), with almost 60\% of them living in South Asia (Ram and Yadav, 2021). According to the International labor organization, about 1.6 billion workers around the world in the informal economy are at immediate risk of losing their prime income source, which may result in the possibility of half of the global workforce losing livelihood due to the pandemic situation (The New York Times, 2020). The slowdown of the economy increased the percentage of people living below the poverty line and will increase by 2\% (Vos et al., 2020). According to Buheji et al. (2020), about 49 million people will be forced into extreme poverty by 2020. The economy of developing countries, particularly Bangladesh, has been severely affected. Lower-income groups, likely street vendors, garment workers, hawkers, transport workers, small job holders of Bangladesh, experienced a massive drop in income (Kabir et al., 2021; Sarkar and Morshed, 2021). Employees in the financial sectors and manufacturing industries lost a third of their total pay. However, most employees have not been able to withstand the pandemic and the economic depression for more than a month (Hossain, 2021). This became a serious threat to the livelihoods of the people, global food security and will cause serious stress to the people, especially lower-income groups.

More people become destitute and food insecure as COVID-19 and its economic ramifications spread throughout the world's poorest regions. Bangladesh is a developing country, with a $4 \%$ unemployment rate, and every year about 2 million educated people are added to the unemployed list. A significant portion of the employed population is from the informal sector (Hossain, 2021). The country has various vulnerabilities that could exacerbate the impacts of the COVID-19 pandemic and may cause a multidimensional crisis. 
In Bangladesh, the first case of COVID was confirmed on March 8, 2020, first death on March 18, 2020. The Bangladesh government imposed a countrywide lockdown (shutdown of all types of transport systems) and declared national holidays from March 26 to April 4, 2020, in order to avoid community dissemination of the epidemic (IEDCR, 2020). The lockdown continued for three months in a row. Due to an upsurge in Delta variants, the country has implemented a second phase lockdown from July 23, 2021 to August 10, 2021 (Morshed and Sarkar, 2021).

The export earnings contribute the most to the GDP of the country, but $\$ 3.15$ billion in orders from the garment manufacturers have already been canceled or placed on hold by fashion companies throughout the world (Sakamoto et al., 2020). The ready-made garments (RMG) sector is not only Bangladesh's most important export earner, but it has also been the engine of the country's economic progress in recent decades. Over 1 million garment workers in Bangladesh have already been sacked or furloughed as a result of order cancellations and customers' failure to pay for these cancellations (Hossain et al., 2021). The three-month-long lockdown and restriction of vehicular activities resulted in the loss of income sources, severely affected the people across the country and caused a severe crisis. This crisis has had a significant influence on mental health, socioeconomic conditions and livelihood. Many people are distressed as a result of the virus's acute health effects and the implications of physical isolation, dread of losing loved ones and dread of dying from hunger (United Nations, 2020; Rajkumar, 2020; Shammi et al., 2020). Marginal individuals, including day laborers, rickshaw drivers, domestic workers, street sellers, transport workers and construction laborers who already lost their jobs as a result of the lockdown and are the worst affected by the outbreak. Furthermore, the lockdown disproportionately affected lowand middle-class people, who lost their employment and other sources of income, resulting in psychological stress, anxiety and the dread of starvation death (Bodrud-Doza et al., 2020; Mamun et al., 2020). Several recent studies have discussed different types of impacts of COVID-19 from a different perspective. Sakamoto et al. (2020) discussed the impacts of the COVID-19 situations on SDGs in Bangladesh in mesoscale. Paul et al. (2020) and Bodrud-Doza et al. (2020) illustrated the psychological impact of the pandemic situation in Bangladesh on different income groups in mesoscale. A limited number of studies assessed the microscale psychological, socioeconomic impacts of COVID-19 on lower-income groups and analyzed the microscale impacts of COVID-19 in attaining SDGs.

The pandemic has caused two types of employment losses in Bangladesh: permanent and temporary lockdown-induced unemployment. About 12 to 17 million Bangladeshis were believed to have lost their jobs during the lockdown (Ahmed and Kamal, 2020). According to The Financial Express (2020), about 5 million people from transport, 7 million from micro, small and medium-level enterprises, 10 million from agriculture, and 6 million from the construction and manufacturing sectors have lost their jobs permanently. Besides the health crisis, this pandemic situation has caused severe impacts on the economy as well as mental health. In this research, we addressed the psychological impacts, socioeconomic impacts, anxiety levels of the lower-income groups of Chittagong City during the COVID-19 pandemics based on the public perception. The study also assessed the impacts of COVID-19 on the attainment of SDGs in the context of the slums of Chittagong City. This investigation may inform the policymakers, government bodies, NGOs, international donors in decision making to mitigate the impacts of COVID-19 for ensuring sustainable development.

\section{Methods and data collection}

\subsection{Study region - Chittagong}

Chittagong is one of the densely populated cities and the second-largest urban areas in Bangladesh. The city has been playing an essential role in the country's economy and

Impacts of COVID-19 outbreaks 
FEBE

2,2

110

regional connectivity within the subcontinent. There is a seaport and three export processing zones (EPZs), namely Chittagong EPZ (CEPZ), Karnaphuli EPZ and Korean EPZ, located in Chittagong, with thousands of factories. More than 1.5 million people work in the CEPZ, and total exports from the CEPZ totaled $\$ 1.67$ billion in 2011 (Mia et al., 2015). The city witnessed a population growth rate of 3.6\% between 1991 and 2001 and $2.3 \%$ between 2001 and 2011 (Mannan et al., 2021). The majority of the residents of Chittagong, especially those living in the southern part of the city, are day laborers and garment workers, as the three EPZs are located here.

The city witnessed the first COVID case on April 2, 2020 and the first death on April 9, 2020 (Dhaka Tribune, 2020). Till December 2021, total deaths accounted for 1,332, with 102,271 positive test results (The Business Standard, 2021). Besides health impacts, the lockdown also impacted employment as well as the economic condition of people around the world. The shutdown of garments and factories has directly affected, decreased work hours, bonus payments and other financial issues. Studies show that the average monthly income fell to its lowest point in April, averaging BDT 5,425 when factories were forced to close for a month by the government (Hossain et al., 2021). Furthermore, people who do not work in the garment industry but are associated with it, such as those in the transportation sector, small businessmen, hawkers and small shop owners, are affected. This made the lives of the lowerincome groups in Chittagong vulnerable. In this study, we have addressed the socioeconomic and mental impacts of the COVID-19 situation and the lockdown on the poor residents of Chittagong City.

\subsection{Data collection}

This study was conducted across Chittagong City, targeting the lower-income group of people, most of them are garment workers and daily income earners. Though there are many poor income respondents in the study area we were capable of taking the responses of only 150 people. Since these groups of people typically have minimal Internet access, we decided to perform physical interviews at a distance of at least 2 meters. For primary data collection, we have conducted field surveys with a group of five people in Chittagong port area, where most of the residents are garment workers, as well as day laborer, transport labor. We chose respondents using convenience sampling, which is the most popular nonprobability sampling technique.

For primary data collection, we have followed both quantitative and qualitative approaches. We have collected the sociodemographic data, psychological, livelihood impact and supply of different services during the COVID phase. This study collected these data through a questionnaire consisting of 15 questions (Table 2). The questionnaire was prepared in both English and the native language of Bangladesh, Bangla and interviewed randomly. Table 1 represents the sociodemographic profile of the respondents in this study. The secondary data has been collected from the "COVID-19 Dynamic Dashboard for Bangladesh (http://dashboard.dghs.gov.bd/webportal/pages/covid19.php)" and other news, reports and published articles.

\subsection{Livelihood and social impact assessment}

For assessing the impact of the pandemic on the livelihood and stress level, the study followed a four-point Likert-type scale $(4=$ extreme, $3=$ high, $2=$ moderate, $1=$ little). Independent samples $t$-test and one-way analysis of variance/ $F$ test were used to compare the mean difference between/among the groups of different sociodemographic characteristics with scores of the level subsistence and anxiety. The $\chi^{2}$ test was performed to show the correlation between several aspects of livelihood and anxiety and various sociodemographic factors. 


\begin{tabular}{|c|c|c|c|c|}
\hline Categories & Groups & Frequency & $\%$ & Impacts of \\
\hline Gender & Man & 95 & $\begin{array}{l}63.33 \\
36.67\end{array}$ & outbreaks \\
\hline \multirow{5}{*}{ Age group } & $\begin{array}{l}\text { Women } \\
>25\end{array}$ & $\begin{array}{l}55 \\
30\end{array}$ & $\begin{array}{l}36.67 \\
20.00\end{array}$ & \\
\hline & $25-35$ & 47 & 31.33 & \\
\hline & $36-45$ & 26 & 17.33 & \\
\hline & $46-55$ & 27 & 18.00 & 111 \\
\hline & Above 55 & 20 & 13.33 & \\
\hline \multirow[t]{5}{*}{ Education } & Primary & 62 & 41.33 & \\
\hline & Secondary & 28 & 18.67 & \\
\hline & Diploma & 10 & 6.67 & \\
\hline & College & 13 & 8.67 & \\
\hline & No education & 37 & 24.67 & \\
\hline \multirow[t]{6}{*}{ Employment } & Unemployed & 15 & 10.00 & \\
\hline & Daily worker & 35 & 23.33 & \\
\hline & Garment worker & 48 & 32.00 & Table 1. \\
\hline & Shop owner & 15 & 10.00 & Respondents' \\
\hline & Small business & 29 & 19.33 & sociodemographic \\
\hline & Industry workers & 8 & 5.33 & profile \\
\hline
\end{tabular}

\section{Results}

\subsection{Sociodemographic status of the respondents}

The study area of this research was some slums in the vicinity of Chittagong EPZ where most of the people are poor and have no formal education. Table 1 shows the majority of the respondents of this study were men $(63.33 \%)$ and aged between 25 and 55 years $(66.67 \%$ of total respondents). About $24.67 \%$ of the total respondents were found illiterate, whereas $41.33 \%$ were within the primary level of education. The failure of education is the leading cause of the poverty of the respondents. Due to poor education levels, most of the respondents were either daily workers $(23.33 \%$ ) or garment workers $(32 \%)$, and a large portion of garment workers were women. Some of the respondents with a diploma background were found working in different small industries.

\subsection{Impacts of COVID-19 on livelihood and psychology}

COVID-19 and lockdown have a significant impact on all classes of people in the community. This study focused on the poor income people, whose monthly income is less than BDT 15,000 $(1 \$=$ BDT 84$)$. Bangladesh government-imposed lockdown all over the country from the last week of March (03/26/2020) which has a significant adverse impact on the lower-income people, especially slum dwellers, who usually have a hand-to-mouth existence. About $97.33 \%$ of the respondents said that their daily life was affected by COVID-19 whereas $89.99 \%$ of them claimed that this impact was high to extreme.

As the lockdown lasted for three months and there has been fasting and Eid in between, most of the respondents suffered much bearing the family expenses. The people of large families and day laborers were highly affected by the lockdown. Though the government of Bangladesh introduced emergency funds for the poorer, none of the respondents of the study area received financial help. About $24 \%$ of respondents said they received relief three to four times from different local organizations but not enough.

This pandemic and lockdown drive more people into unemployment and poverty. Lack of money for food, house rent and daily expenses due to lockdown impacted much on people's livelihood. Table 3 represents the score of the impact of COVID-19 on the livelihood of the respondents during the lockdown. The livelihood impact was assessed by four-point Likert- 
FEBE

2,2

\begin{tabular}{|c|c|c|}
\hline Questions & Response & $\%$ \\
\hline \multirow[t]{2}{*}{ Went outside? } & Yes & 90.00 \\
\hline & No & 10.00 \\
\hline \multirow[t]{2}{*}{ Received relief? } & Yes & 24.00 \\
\hline & No & 76.00 \\
\hline \multirow[t]{2}{*}{ Received money? } & Yes & 10.00 \\
\hline & No & 90.00 \\
\hline \multirow[t]{2}{*}{ Is your livelihood affected by Covid? } & Yes & 97.33 \\
\hline & No & 2.67 \\
\hline \multirow[t]{4}{*}{ If yes? Define the level } & Extreme & 41.33 \\
\hline & High & 48.66 \\
\hline & Moderate & 5.34 \\
\hline & Little & 4.67 \\
\hline \multirow[t]{2}{*}{ Do you face domestic violence? } & Yes & 75.33 \\
\hline & No & 24.67 \\
\hline \multirow[t]{3}{*}{ Your income levels? } & Decreased & 90.00 \\
\hline & Not changed & 7.33 \\
\hline & Increased & 2.67 \\
\hline \multirow[t]{2}{*}{ Food habit? } & Deteriorated & 74.67 \\
\hline & Not changed & 25.33 \\
\hline \multirow[t]{2}{*}{ Is your child's education affected? } & Yes & 95.33 \\
\hline & No & 4.67 \\
\hline \multirow[t]{3}{*}{ Social security? } & Improved & 11.33 \\
\hline & Not changed & 16.00 \\
\hline & Deteriorated & 72.67 \\
\hline \multirow[t]{3}{*}{ Water supply and sanitation condition } & Improved & 0.00 \\
\hline & Not changed & 28.00 \\
\hline & Deteriorated & 72.00 \\
\hline \multirow[t]{3}{*}{ Access to health service facility condition? } & Improved & 0.00 \\
\hline & Not changed & 11.00 \\
\hline & Deteriorated & 89.00 \\
\hline \multirow[t]{3}{*}{ Hygiene consciousness and practice? } & Increased & 76.66 \\
\hline & Decreased & 8.67 \\
\hline & No change & 14.67 \\
\hline \multirow[t]{2}{*}{ Do you feel stressed about the pandemic? } & Yes & 96.67 \\
\hline & No & 3.33 \\
\hline \multirow[t]{4}{*}{ If yes? Define the level } & Extreme & 53.79 \\
\hline & High & 35.17 \\
\hline & Moderate & 8.28 \\
\hline & Little & 2.76 \\
\hline
\end{tabular}

type scale $(4=$ extreme, $3=$ high, $2=$ moderate $1=$ little). The overall livelihood score $3.22 \pm 0.67$ indicates that the impact of COVID-19 on the livelihood of the respondents during the lockdown was high to extreme. This score differed significantly $(\phi<0.01)$ depending on the age group, gender and employment. Table 2 shows that among different occupations, the impact was prominent in daily workers $(3.40 \pm 0.51)$ and garment workers $(3.37 \pm 0.66)$. Regarding the age group, the prominent affected group were the respondents' aged between 25 and 35 (3.44 \pm 0.61$)$, and most were women.

Since Bangladesh is an emerging country, the poor's lives were jeopardized as a result of the lockdown. After a few days of lockdown, the public, especially the lower-income people (such as dwellers, day laborers, hawkers) began to venture outside in search of work. More than $70 \%$ of the respondents ignored the lockdown and regularly went outside and they feared death from starvation rather than coronavirus. About $96.67 \%$ of the respondents claimed that they were under stress due to financial problems and other problems because of 


\begin{tabular}{|c|c|c|c|c|c|c|c|c|}
\hline Categories & Groups & $\operatorname{LLI}(\bar{x} \pm s)$ & $t / F$ test & $P$ & $\operatorname{LOS}(\bar{x} \pm s)$ & $t / F$ test & $P$ & Impacts of \\
\hline Gender & $\begin{array}{l}\text { Man } \\
\text { Women }\end{array}$ & $\begin{array}{l}3.37 \pm 0.51 \\
3.21 \pm 0.60\end{array}$ & 3.213 & 0.004 & $\begin{array}{l}3.26 \pm 0.64 \\
3.30 \pm 0.61\end{array}$ & -0.154 & -0.880 & outbreaks \\
\hline Age group & $\begin{array}{l}>25 \\
25-35 \\
36-45 \\
46-55 \\
\text { Above } 55\end{array}$ & $\begin{array}{l}2.86 \pm 0.67 \\
3.44 \pm 0.61 \\
3.25 \pm 0.65 \\
3.26 \pm 0.71 \\
3.01 \pm 0.58\end{array}$ & 11.981 & 0.000 & $\begin{array}{l}3.17 \pm 0.73 \\
3.23 \pm 0.69 \\
3.29 \pm 0.58 \\
3.14 \pm 0.78 \\
2.85 \pm 0.73\end{array}$ & 4.962 & 0.002 & 113 \\
\hline Education & $\begin{array}{l}\text { Primary } \\
\text { Secondary } \\
\text { Diploma } \\
\text { College } \\
\text { No education }\end{array}$ & $\begin{array}{l}3.29 \pm 0.63 \\
3.34 \pm 0.64 \\
3.00 \pm 0.68 \\
3.13 \pm 0.51 \\
3.39 \pm 0.54\end{array}$ & 2.151 & 0.053 & $\begin{array}{l}3.33 \pm 0.61 \\
3.25 \pm 0.65 \\
2.98 \pm 0.77 \\
3.21 \pm 0.78 \\
3.38 \pm 0.76\end{array}$ & 0.991 & 0.408 & \\
\hline Employment & $\begin{array}{l}\text { Unemployed } \\
\text { Daily worker } \\
\text { Garment worker } \\
\text { Shop owner } \\
\text { Small business } \\
\text { Industry worker }\end{array}$ & $\begin{array}{l}3.18 \pm 0.69 \\
3.40 \pm 0.51 \\
3.37 \pm 0.66 \\
2.81 \pm 0.69 \\
2.97 \pm 0.81 \\
3.05 \pm 0.78\end{array}$ & 6.758 & 0.000 & $\begin{array}{l}2.83 \pm 0.86 \\
3.28 \pm 0.71 \\
3.39 \pm 0.59 \\
2.99 \pm 0.81 \\
3.30 \pm 0.67 \\
3.24 \pm 0.63\end{array}$ & 3.17 & 0.012 & $\begin{array}{r}\text { Table } 3 . \\
\text { The score of the level of } \\
\text { livelihood and }\end{array}$ \\
\hline $\begin{array}{l}\text { Overall } \\
\text { Note(s): LLI }\end{array}$ & \multicolumn{7}{|c|}{ Note(s): LLI = Livelihood impacts, LOS = Level of stress } & $\begin{array}{r}\text { psychological impacts } \\
\text { of COVID }\end{array}$ \\
\hline
\end{tabular}

the pandemic. The score of the stress level in Table 3 shows that the overall score of level of stress $3.19 \pm 0.68$ indicates the high to the extreme level of stress. About $53.79 \%$ of respondents claimed defined extreme stress level and 35.17 high-stress levels (Table 2). Prominent stress level score found for the garment workers because of the fear of job, house rents. The shop owners were less stressed as most of them had permissions to keep the shop open, especially the grocery shops and pharmacies. Table 3 represents the score of the stress level of different sociodemographic groups with $t$-test and $p$-value.

\subsection{Impacts of COVID-19 on employment and economic condition}

The government of Bangladesh imposed a three-month-long lockdown and declared public holidays, which impacted all social classes in many ways. The assessment of the impact of COVID-19 on lower-income groups, especially slum dwellers, shows the severe economic impact of the pandemic. About $29.33 \%$ of the respondents lost their jobs, $20.67 \%$ changed their occupations. Regarding the occupation categories, about $80 \%$ of the daily workers became unemployed, and $10 \%$ of the garment workers lost their job and $15 \%$ changed occupation during the pandemic. Figure 1 shows that a significant percentage of the respondents have changed their jobs. Many of them started working as food delivery boys (Foodpanda, Pathao, etc.). The women suffered mostly due to lockdown. Among the age groups, the percentage of the respondents' lost jobs was higher in the classes of more than 46 years old. About $90 \%$ of the respondents claimed that their income level had decreased (Table 2). Many of them became jobless, whereas a significant portion of the respondents said that their salaries had been reduced. Only the income level of the shop-owners $(2.67 \%)$ was increased. Table 4 shows the impacts of COVID-19 on the economic condition of different sociodemographic groups of the respondents.

\subsection{Impacts of COVID-19 on food habit}

The lockdown and the deterioration of the economic condition of the respondents have significantly affected the food habits of the lower-income groups. The three-month-long 


\section{FEBE \\ 2,2}

\section{4}

Figure 1.

Lockdown and employment status of the respondents

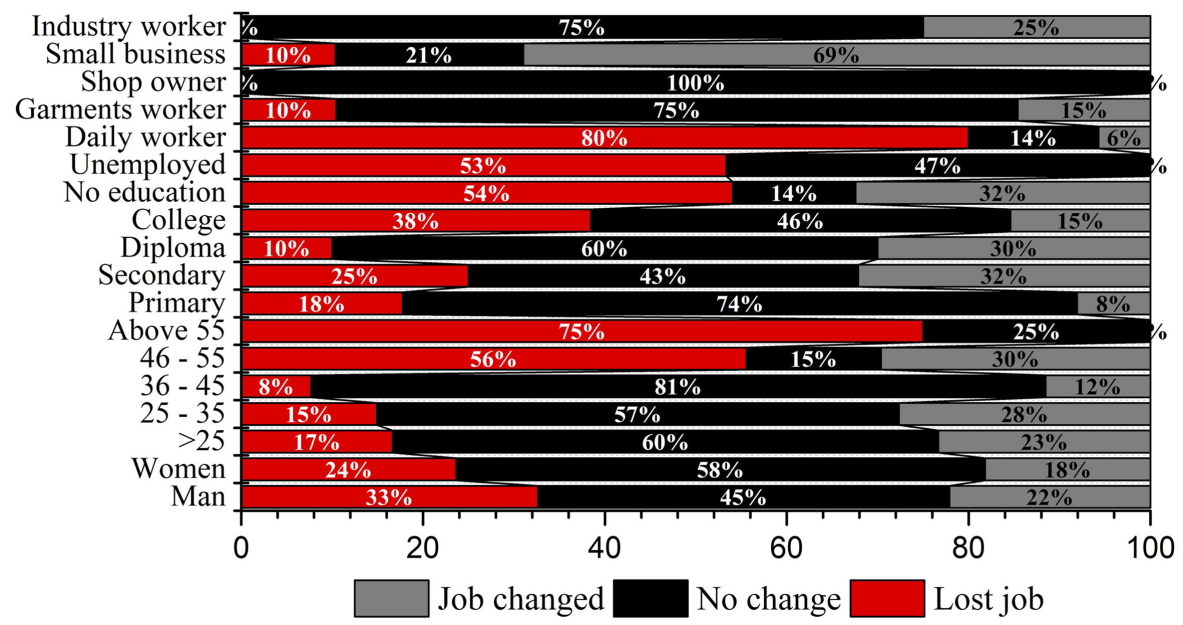

lockdown has affected all classes of people with a lower supply of food, increased commodity prices and financial crisis, but it was a tragedy for the lower-income groups. Table 2 shows that about $74.67 \%$ of the respondents said that they have faced the food crisis. Most of them had no money to buy food, and large families were found to take loans from relatives or local NGOs, sold deposited jewelry to buy food. Among the age groups, respondents aged more than 46 years suffered the most, as the income level of this group decreased the most. Only $24 \%$ of the respondents received relief, and $10 \%$ of them got financial help from locals and others. As a result, the poor people had to move outside in search of food, and $90 \%$ of them went outside (Table 2).

\subsection{Lockdown and domestic violence}

One of the major adverse effects of the COVID-19 lockdown is the increase in domestic violence in the slums. A large portion of the respondents (75.33\%, Table 2$)$ acknowledged that domestic violence had largely increased during the lockdown. Women and children are suffering from this increased violence. The long-term financial crisis, food crisis, health problems and lockdown have increased family unrest and domestic violence. Table 3 shows that $81.82 \%$ of the female respondents are victims of domestic violence and said that domestic violence has increased. About $95.83 \%$ of the garment workers agreed with the increase in domestic violence. The study found that domestic violence increased mostly in large families whose incomes had decreased or lost jobs.

\subsection{COVID-19 and hygiene consciousness}

The coronavirus has greatly increased hygiene awareness among people all over the world. Table 2 shows that the fear of coronavirus increased health and hygiene awareness among $76.67 \%$ of the respondents, but the awareness has been reduced with time. Though people are more aware than before, the financial condition has influenced them to reduce the use of hygiene. Most of the respondents said that they used sanitizers and masks regularly, but this has decreased over time. The respondents blamed the financial crisis and unemployment for this. About $14.67 \%$ of the respondents said that they are conscious but do not use hand sanitizers or masks. But they were more aware of food hygiene than ever before. The field survey found that the increase in the price of goods decreased the practice of hygiene by 


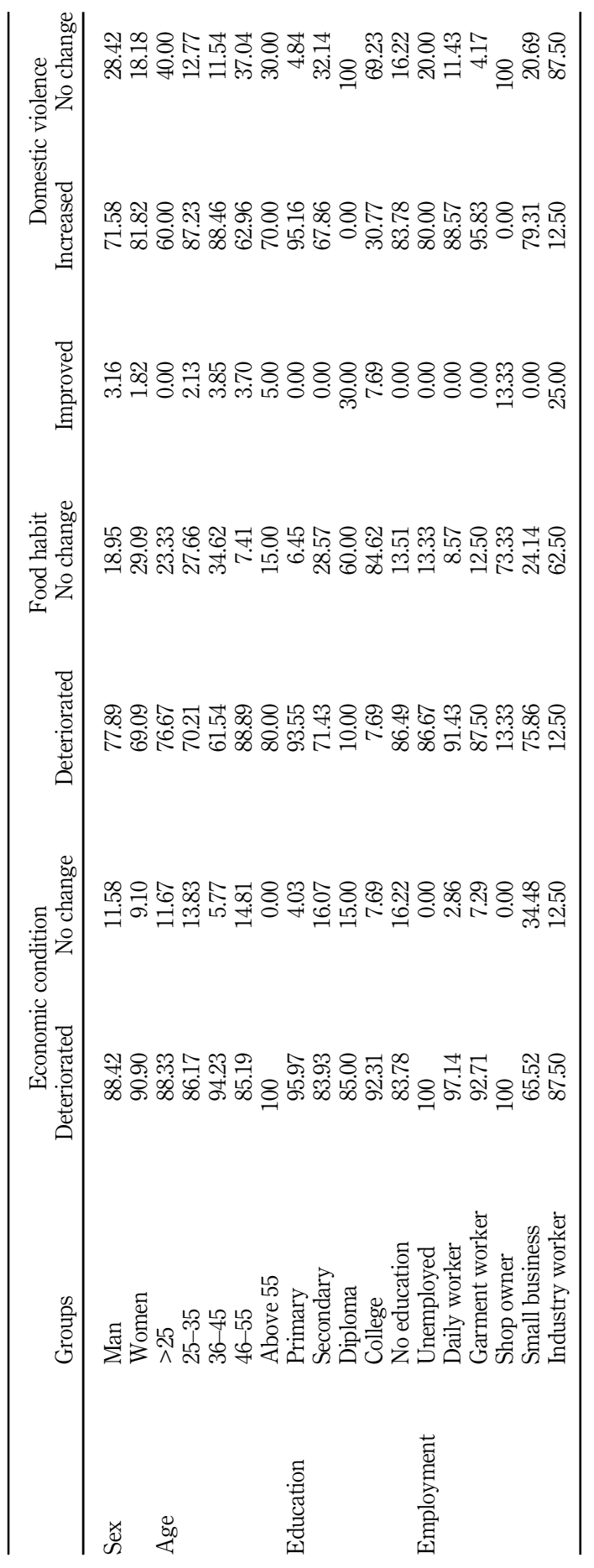

Impacts of

COVID-19 outbreaks

115

Table 4. Impacts of lockdown on economic condition, food habit and domestic violence 
FEBE

2,2

\section{6}

Figure 2.

Slum-dwellers perception about the impact of COVID-19 pandemic on service facilities
$8.67 \%$ of the respondents in the study area. Despite this, most of the respondents were found using face masks.

\subsection{Impacts of COVID-19 on education}

The lockdown and severity of the coronavirus have forced the government to close all the educational institutions in Bangladesh. After three months of the closure of educational institutions, the government started online educational activities. Lack of necessary devices such as the Internet, smartphone/laptop students from lower-income families failed to participate in online education activities. This image has been found in the study area. About $95.53 \%$ (Table 2, Figure 2) of the respondents said that they were unable to provide devices to their children, and because of this, their children were being deprived of education. Two respondents said that this situation forced them to give their daughters child marriages. Table 2 shows that only $4.47 \%$ of respondents said that their children's education was not affected that much, as they were capable of providing devices. The respondents were seen in fear about the children and badly sought help. The student found that the most sufferers are the daily labor groups and garment workers and the not affected respondents are from the shop-owner and industry worker groups.

\subsection{Impacts of COVID-19 on the progression of slums towards sustainability}

The study found that the slum dwellers or the respondents of this study are facing good water supply and sanitation problems during the pandemic situation. About $72 \%$ of the respondents responded that the condition has been deteriorating since the lockdown (Figure 2). They claimed that they had to share toilets with other families in this pandemic situation. Lockdown has resulted in increased use of toilets due to constant stay at home, and they have to wait longer than before. This has also increased the use of water much more than before. About $28 \%$ of the respondents said that the water supply and sanitation facilities remained the same as before. We found that they have private toilets inside their house.

The pandemic also affected the poor people in health service facilities. The respondents have expressed dissatisfaction with the medical service due to the closure of local doctor's chambers during the pandemic situation. Figure 2 shows that about $89 \%$ of the respondents claimed the deterioration of the health service facilities. They blamed the increase in COVID patients in the hospitals, the poor service facilities of the hospitals, the lack of doctors, the poor transport system for going to the hospital and the increase in the price of drugs for this deterioration.

\section{Discussion}

\subsection{Lockdown and socioeconomic impact}

The effect of the COVID pandemic on the poor is increasing day by day, owing to job losses and other income shocks and diminished livelihoods. Poor households and those who rely

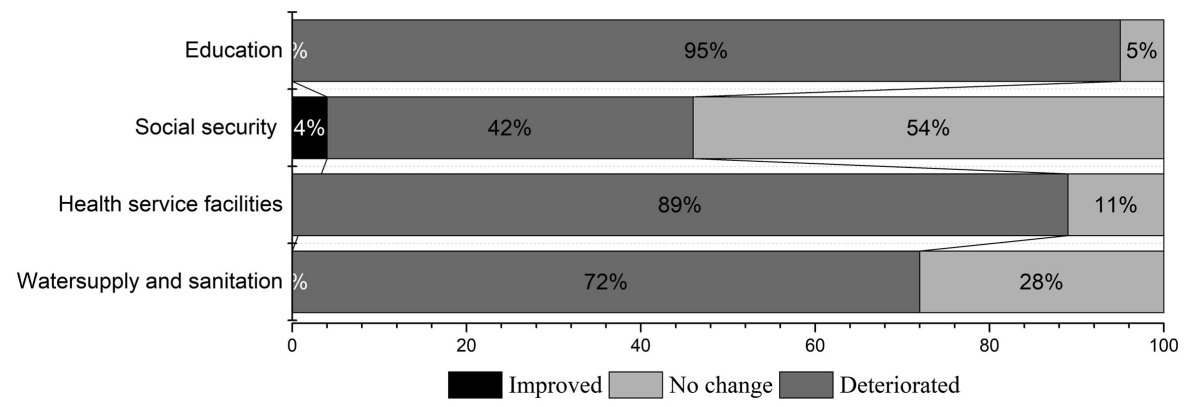


on informal jobs are among the most disadvantaged members of society. The urban areas around the world have become the epicenter of this COVID pandemic. The long-term lockdown has caused serious economic loss to the city and disrupted the normal life of the people. Reduction of earning opportunities has significantly affected the ability of people to buy foods, travel restrictions have profoundly impacted the supply of fresh food, and the strict restrictions have had high costs for many (Sakamoto et al., 2020). The lower-income groups, especially slum dwellers are the biggest sufferer of this pandemic. This study assessed the socioeconomic impacts of the COVID-19 outbreaks on the livelihood of the poor income groups of Chittagong City, where most of the people are garment workers. The immediate effect for those who had employment was that they were lost. The closing of the garment factories meant that those who had previously worked there were not compensated. Many who relied on petty trading were unable to do so any longer - in addition to being physically prevented from trading, there were no buyers. According to Bodrud-Doza et al. (2020), many middle- and lower-income people in Bangladesh lost their jobs and income sources during the pandemic. Ibrahim et al. (2020) reported that the loss of salaries and employment in Bangladesh would further marginalize more than 10 million people. The three month-long lockdowns made the poor more impoverished. Many slum dwellers in Chittagong City said they had nothing to eat and some said they hadn't lit their stove for many days. This study shows that the financial crisis of the slum dwellers has significantly increased the stress and affected their livelihood. Analysis shows that the scores of the stress and livelihood were high to extreme, which indicates the serious impacts of COVID outbreaks and lockdown on the socioeconomic conditions of the lowerincome people. This also increased domestic violence. Similar livelihood impacts have been illustrated by Paul et al. (2020) on the lower-income people across the different cities of Bangladesh.

\subsection{Lockdown and sustainability}

COVID-19 poses a serious threat to the attainment of SDGs (Sakamoto et al., 2020; Josephson et al., 2021) and leads to severe and acute economic losses in many countries (Martin et al., 2020). When the countries around the world continue to strive to achieve the SDGs by 2030, the COVID-19 has become a major obstacle to progress. Developing countries are more affected by this progression than developed countries (Josephson et al., 2021). Bangladesh is no longer an exception. Bangladesh is one of the high-risk countries during the COVID-19 pandemic due to several vulnerabilities (Sakamoto et al., 2020). Due to lockdown, the second largest foreign exchange earning source, garment factories were widely hampered due to the close of imports and exports, which profoundly affected garment workers, especially the working class. This study assessed the impacts of COVID-19 outbreaks on lower-income people, especially those living in the slums beside the CEPZ. The results of this study illustrated the severe socioeconomic impacts of the COVID-19 outbreaks on the slum dwellers. The assessment of the impacts of the lockdown on slums sustainability demonstrates that COVID-19 has made it more critical to achieving some of the goals of SDGs. This study showed that many slum dwellers lost their jobs and income sources, which made it more critical to attaining SDG 1 (No poverty), an increase in domestic violence made it more critical to attaining SDG 5.1 and 5.2 ("End all forms of discrimination against all women and girls everywhere" and "Eliminate all forms of violence against all women and girls in the public and private spheres, including trafficking and sexual and other types of exploitation") and also SDG 16, degradation of health conditions to attain SDG 3 ("Ensure healthy lives and promote well-being for all at all ages"), poor water supply and sanitation conditions in achieving SDG 6 ("Ensure availability and sustainable management of water and sanitation for all"), deterioration of slum dwellers' food habits to attain SD 2 ("End hunger, achieve food 
FEBE

2,2

security and improved nutrition and promote sustainable agriculture") and failure of slum children in continuing online education activities in attaining SDG 4 ("Quality education").

\section{Conclusion}

Coronaviruses are continually changing due to mutations, and these alterations sometimes result in new viral strains. The outbreaks of each variant spread quickly, resulting in many infected cases, including deaths. To minimize the rapid transmission of the virus, governments around the world were compelled to impose lockdowns several times. The severity of COVID-19 outbreaks has significantly deteriorated social, economic and psychological conditions and affected livelihoods all over the world. Despite the fact that all socioeconomic classes have been affected, the poor have become more vulnerable. The COVID-19 epidemic has put people's lives in jeopardy in developing countries, where the majority of people depend on daily income. This study documented the impacts of the pandemic on the livelihoods of lower-income groups on a microscale in the context of a densely populated city and also illustrated the impacts of the pandemic on attaining SDGs. The long-term lockdowns exacerbated the financial crisis among the lower-income groups, led to extreme livelihood impacts, psychological stress, deteriorated food habits, increased domestic violence and affected access to basic service facilities and educational activities. This made it critical to attaining some of the targets of SDGs for Bangladesh. This study only focused on the lower-income groups and slum dwellers and illustrated the impacts of COVID-19 on the attainment of SDGs on the microscale. Further study can focus on mesoscale inventory analysis with spatial mapping to illustrate the intensity of the pandemic severity among all income groups across the country. The findings of this study will attract government, policymakers, NGOs to measure prevention strategies to mitigate such serious problems with sustainable solutions.

\section{References}

Ahmed, I. and Kamal, S.M. (2020), "Bangladesh at work in the era of COVID-19: job creation and inclusive growth", Bdnews24.com, available at: https:/opinion.bdnews24.com/2020/06/04/ bangladesh-at-work-job-creation-and-inclusive-growth-in-the-eraof-covid-19/.

Arab News (2020), "Starving' Bangladesh garment workers protest for pay during COVID-19 lockdown", 13 April 2020, available at: https:/www.arabnews.com/node/1658186/world (accessed 28 July 2020).

Bodrud-Doza, M., Shammi, M., Bahlman, L., Islam, A.R. and Rahman, M. (2020), "Psychosocial and socio-economic crisis in Bangladesh due to COVID-19 pandemic: a perception-based assessment”, Front Public Health, Vol. 8, p. 341.

Buheji, M., da Costa Cunha, K., Beka, G., Mavric, B., Leandro do Carmo de Souza, Y., Souza da Costa Silva, S., Hanafi, M. and Chetia Yein, T. (2020), "The extent of COVID-19 pandemic socioeconomic impact on global poverty. a global integrative multidisciplinary review", American Journal of Economics, Vol. 4, pp. 213-224.

Dhaka Tribune (2020), "First child dies from coronavirus in Chittagong", available at: https://archive. dhakatribune.com/health/coronavirus/2020/04/13/another-coronavirus-patient-dies-inchittagong (accessed 10 January 2022).

Hossain, M.I. (2021), "COVID-19 impacts on employment and livelihood of marginal people in Bangladesh: lessons learned and way forward", South Asian Survey, Vol. 28 No. 1, pp. 57-71, doi: $10.1177 / 0971523121995072$.

Hossain, J., Akter, A. and Ahmed, M. (2021), "The impact of the pandemic on garment workers in Bangladesh", Fair Wear, available at: https://www.fairwear.org/stories/two-fair-wearcommissioned-reports-uncover-the-impact-of-covid-19-on-the-garment-sector-in-bangladesh/. 
Ibrahim, A., Kabir, N., Khan, A.K., Manzur, S.N. and Reaz, M.M. (2020), "To open or not to open: lockdown exit strategies can help", available at: https://tbsnews.net/analysis/open-or-notopenlockdown-exit-strategies-can-help-76351?fbclid (accessed July 2020).

Institute of Epidemiology, Disease Control and Research (IEDCR) (2020), "Bangladesh Covid-19 update", 24 May 2020, available at: http://iedcr.gov.bd (accessed 29 July 2020).

Josephson, A., Kilic, T. and Michler, J.D. (2021), "Socioeconomic impacts of COVID-19 in low-income countries”, Nature Human Behaviour, Vol. 5, pp. 557-565, doi: 10.1038/s41562021-01096-7.

Kabir, M.R., Islam, M.A. and Hossain, M.Z. (2021), "Socioeconomic impact of Covid-19 on the lower middle and lower income people in Bangladesh", AIP Conference Proceedings, p. 2347, doi: 10. 1063/5.0051652.

Mamun, M.A., Siddique, A.B., Sikder, M.T. and Griffiths, M.D. (2020), "Student suicide risk and gender: a retrospective study from Bangladeshi press reports", International Journal of Mental Health Addiction, Vol. 2020, doi: 10.1007/s11469-020-00267-3.

Mannan, S., Shaheen, M.A. and Saha, R. (2021), "COVID-19: Chittagong port and aftermath”, WMU Journal of Maritime Affairs, Vol. 20, pp. 247-264, doi: 10.1007/s13437-021-00234-2.

Martin, A., Markhvida, M., Hallegatte, S. and Walsh, B. (2020), "Socio-economic impacts of COVID-19 on household consumption and poverty", Economics of Disasters and Climate Change, Vol. 4, pp. 453-479, doi: 10.1007/s41885-020-00070-3.

Mia, M.A., Nasrin, S., Zhang, M. and Rasiah, R. (2015), “City profile Chittagong, Bangladesh”, Cities, Vol. 48, pp. 31-41, doi: 10.1016/j.cities.2015.05.011.

Morshed, M.M. and Sarkar, S.K. (2021), "Common factors of COVID-19 cases and deaths among the most affected 50 countries", Diabetes and Metabolic Syndrome Clinical Research and Reviews, Vol. 15 No. 5, doi: 10.1016/j.dsx.2021.102247.

Naydera, I.N. and Onditi, F. (2020), "COVID-19 experience among slum dwellers in Nairobi: a double tragedy or useful lesson for public health reforms?", International Social Work, Vol. 63 No. 6, pp. 1-4, doi: 10.1177/0020872820944997.

Paul, A., Nath, T.K., Mahanta, J., Sultana, N.N., Kayes, A.S.M.I., Noon, S.J., Jabed, M.A., Podder, S. and Paul, S. (2020), "Psychological and livelihood impacts of COVID-19 on Bangladeshi lower income people", Asia Pacific Journal of Public Health, Vol. 33 No. 1, pp. 100-108, doi: 10.1177/ 1010539520977304.

Rahman, H.Z., Matin, I., Banks, N. and Hulme, D. (2021), "Finding out fast about the impact of Covid19: the need for policy-relevant methodological innovation", World Development, Vol. 140, 105380, doi: 10.1016/j.worlddev.2020.105380.

Rajkumar, R.P. (2020), "COVID-19 and mental health: a review of the existing literature", Asian Journal of Psychiatry, Vol. 52, 102066.

Ram, K. and Yadav, S. (2021), "The impact of COVID-19 on poverty estimates in India: a study across caste, class and religion", Contemporary Voice of Dalit, Vol. 2021, pp. 1-15, doi: 10.1177/ $2455328 X 211051432$.

Sakamoto, M., Begum, S. and Ahmed, T. (2020), "Vulnerabilities to COVID-19 in Bangladesh and a reconsideration of sustainable development goals”, Sustainability, Vol. 12 No. 13, p. 5296, doi: 10. 3390/su12135296.

Sarkar, S.K. and Morshed, M.M. (2021), "Spatial priority for COVID-19 vaccine rollout against limited supply”, Heliyon, Vol. 7 No. 11, doi: 10.1016/j.heliyon.2021.e08419.

Shammi, M., Bodrud-Doza, M., Islam, A.R. and Rahman, M.M. (2020), "COVID-19 pandemic, socioeconomic crisis and human stress in resource-limited settings: a case from Bangladesh", Heliyon, Vol. 22, e04063.

The Business Standard (2021), "Ctg reports one Covid death after 19 days", available at: https://www. tbsnews.net/coronavirus-chronicle/covid-19-bangladesh/ctg-reports-death-covid-after-19-days343423 . 
FEBE

2,2
The Financial Express (2020), "Jobless recovery might put progress of last decade at risk: study", The Financial Express, available at: https:/www.thefinancialexpress.com.bd/economy/bangladesh/ jobless-recovery-might-put-progress-of-last-decade-at-riskstudy-1593175397.

The New York Times (2020), “Instead of coronavirus, the hunger will kill us.' A global food crisis loom”, available at: https://www.nytimes.com/2020/04/22/world/africa/coronavirus-hungercrisis.html (accessed 26 July 2020).

United Nations (2020), "Policy brief: COVID-19 and the need for action on mental health", available at: https://unsdg.un.org/sites/default/files/2020-05/UN-Policy-Brief-COVID-19-and-mental-health. pdf (accessed 27 July 2020).

Vos, R., Martin, W. and Laborde, D. (2020), "As COVID-19 spreads, no major concern for global food security yet", available at: https://www.ifpri.org/blog/covid-19-spreads-no-major-concern-globalfood-security-yet (accessed 26 July 2020).

\section{Corresponding author}

Md. Abdul Fattah can be contacted at: mafattah.kuet@gmail.com

For instructions on how to order reprints of this article, please visit our website: 